\title{
POLA ASUH ORANG TUA BERHUBUNGAN DENGAN PERKEMBANGAN EMOSI (EQ) ANAK
}

\author{
Eny Astuti \\ enyastutiserang@gmail.com \\ STIKes William Booth Surabaya. Jalan. Cimanuk No.20 Surabaya 60241
}

\begin{abstract}
ABSTRAK
Pola asuh merupakan cara orang tua yaitu ayah dan ibu dalam memberikan kasih sayang dan cara mengasuh yang mempunyai pengaruh yang besar bagaimana anak melihat dirinya dan lingkungannya. Orang tua mempunyai peranan yang sangat penting bagi perkembangan prilaku moral pada anak, karena dasar prilaku moral pertama di peroleh anak dari dalam rumah. Karakteristik pada anak yang pertama yaitu egoisentris pada anak prasekolah tidak berarti mereka tidak melihat sesuatu dari pandangan orang lain, karakteristik yang kedua yaitu kelakuan berfikir adalah kecendrungan berfikir hanya pada satu pandangan dan mengabaikan pandangan yang lain. Tujuan penelitian ini adalah untuk mengetahui hubungan pola asuh orang tua terhadap perkembangan emosi (EQ) pada anak prasekolah. Desain yang digunakan dalam penelitian ini adalah desain deskriptif. Sample diambil secara total sampling dengan responden 67 orang. Pengambilan data dilakukan melalui kuisoner. Berdasarkan hasil pengamatan didapatkan bahwa 20 orang $(80 \%)$ dari total 25 orang yang mempunyai anak prasekolah menggunakan gaya pola asuh Lissez-Faire memiliki tingkat emosi (EQ) anak tidak baik. Hasil uji statistik menggunakan spearman menunjukkan nilai $\mathrm{p}=0,006$ yang artinya ada hubungan pola asuh orangtua dengan perkembangan emosi (EQ) anak. Disarankan orangtua untuk tidak menggunakan pola asuh LissezFaire.
\end{abstract}

Kata kunci: pola asuh orang tua, emosi (EQ) anak pada anak prasekolah

\begin{abstract}
Parenting is a form of parental interaction with children during activities lasting parenting, parents guide, lead, educate, and discipline the child to reach maturity and is able to adapt to the environment. In fact there are many children who cry and lock him self in his room. This study uses correlation design, which aims to address the relationship parenting parents who have preschool children in a residential block CA Kahuripan Sidoarjo. Total sample of 67 respondents who met the inclusen criteria. Independent variables in this study are parenting parents while the dependent variabele is the development of emotional (EQ). Data were collected through questionnaire and interviews. The results of this study the majority of people in residential blocks CA Kahuripan Sidoarjo using Laissez-Faire parenting (37\%). While the emotional development of preschool children in a residential block CA Kahuripan Sidoarjo emotional (EQ) is not good (69\%). Spearman's statistical test with a significance of $\rho<0,006$. Thus it can be concluded Ho rejected, which means there is the emotional development of preschoolers. So parents should be able to choose which apply appropriate parenting for their children.
\end{abstract}

Keywords: Parents parenting, Emotional development (EQ) 


\section{PENDAHULUAN}

Pola asuh merupakan bentuk interaksi orang tua dengan anak selama kegiatan pengasuhan yang berlangsung, orang tua membimbing, memimpin, mendidik, dan mendisiplinkan anak untuk mencapai kedewasaan dan mampu beradaptasi dengan lingkungan yang ada dan memahami norma yang berlaku. orang tua mempunyai peranan yang sangat penting bagi perkembangan prilaku moral pada anak, karena dasar prilaku moral pertama di peroleh anak dari dalam rumah. Proses perkembangan melalui pendidikan di sekolah hanya melanjutkan perkembanagan yang sudah ada. Menurut Baumrind (Santrock, 2002) ada empat macam bentuk pola asuh yang diterapkan oleh masingmasing orang tua, bentuk-bentuk pola asuh itu adalah (pola asuh otoriter, pola asuh demokrasi, pola asuh penelantaran dan pola asuh permisif). Dari keempat bentuk pola asuh dapat membentuk emosi (EQ) seseorang anak karena pola asuh berperan penting dalam dalam membentuk karakteristik pribadi atau karakteristik anak (tingkah laku) yang baik atau buruk. EQ (Emotional Inteligence) yaitu kemampuan untuk memantau dan mengendalikan perasaan sendiri dan orang lain. Berdasarkan kenyataan yang dilihat peneliti, masih banyak anak suka membrontak saat disuruh makan atau saat anak asik dengan mainanya, suka menangis saat ditinggal orang tuanya, dan saat keinginannya tidak dipenuhi anak cenderung menangis dan mengurung diri dikamar.

Hasil penelitian psikolog USA menyimpulkan kesuksesan dan keberasilan seseorang dalam menjalani kehidupan sangat didukung kecerdasan emosional (EQ) sebanyak $80 \%$ (www.maenmaen.com, 2013), Hasil pengamatan di dapatkan di indonesia $71 \%$ emosi (EQ) pada anak usia 3 sampai 5 tahun banyak anak mengalami hiperaktif, cenderung nakal ,manja, suka membantah, membrontak, berani dan egois diukur dari pola asuh orang tua dalam menerapkan 4 tipe pola asuh, sedangan persentase emotional intelligence anak di jawa timur didapatkan $60 \%$ anak cenderung malas, dan tidak mandiri, sedangkan hasil pengamatan oleh peneliti di perumahan kahuripan nirwana blok CA banyak anak anak prasekolah didapatkan 53\% banyak anak - anak yang masih belum bisa mandiri, dan cenderung egois dapat diukur dari pola asuh orang tua. Hasil penelitian menunjukkan bahwa tipe pola asuh demokratis merupakan pola asuh yang terbanyak yang diterapkan oleh orang tua kepada anaknya karena pola asuh demokratis mempunyai prinsip mendorong anak untuk mandiri, tapi orang tua tetap menetapkan batas dan kontrol. Orang tua biasanya bersikap hangat, dan penuh welas asih kepada anak, bisa menerima alasan dari semua tindakan anak, mendukung tindakan anak yang konstruktif, dan tidak sedikitpun mengarahkannya secara otoriter. Hal ini sesuai dengan hasil Ada orang tua yang memandang bahwa anak merupakan suatu yang sangat didambakan oleh keluarga karena dianggap akan menjadi penyambung silsilah untuk generasi mendatang dengan segala citra yang indah, maka orang tua bersikap dan memperlakukan anak dengan cara berlebihan. Aktivitas dan pergaulan anak sangat dibatasi, banyak larangan yang kadang-kadang tidak jelas alasannya. Sebaliknya orang tua berusaha semaksimal mungkin dalam memenuhi segala permintaan anak tanpa melihat dan mempertimbangkan apakah permintaan itu masih dalam batas kewajaran. Sikap yang demikian protektif tersebut dapat menyebabkan anak cenderung bersifat manja, kurang kreatif dan rendah tingkat kemandiriannya, dan pada akhirnya membuat status emosinya kurang stabil (Grahacendikia, 2009).

Masa depan anak akan tergantung dari pengalaman yang didapatkan anak termasuk faktor pendidikan dan pola asuh orang tua, disaat sekarang ini tidak sedikit orang tua yang mengejar kepentingan mereka sendiri dengan dalil untuk kesejatraan anak, sehingga terkadang peran mereka sebagai orang tua yaitu mendidik dan mengasuh anak terlantarkan. Tidak hanya kebutuhan fisik saja tetapi kebutuhan psikologis juga menentukan perkembangan anak ke arah kedewasaan yang mantap dan menyeluruh (Habibi, 2007). Orang tua lupa 
atau tidak mengetahui bahwa tanggung jawab mereka yang paling penting sebgai orang tua adalah mendengarkan anak mereka. Bukan hanya mendengarkan katakata mereka, melainkan juga perasaan di balik kata-kata mereka. Jika orang tua melalaikan tugas mereka sebagai pengasuh anak dapat berdampak pada kestabilan emosi anak. Sehingga anak cenderung tidak dapat mengontrol emosi yang berupa ketakutan, kemarahan, agresi, kejengkelan, dan marah.

Keberhasilan pembentukan karakter pada anak ini salah satunya dipengaruhi oleh pola asuh orang tua.Pola asuh orang tua terbagi menjadi tiga macam yaitu otoriter, permisif, danotoritatif.Masing masing polah asuh ini mempunyai dampak bagi perkembangan anak.Karena pola asuh otoritatif menjadi jalan terbaik dalam pembentukan karakteranak.Karena pada pola otoritatif ini berincikan orang tua bersikap demokratis, menghargai dan memahami keadaan anak dengan kelebihan kekuranganya sehingga anak dapat menjadi pribadi yang matang, supel,dan bias menyesuaikan diri dengan baik. Melalui pola asuh otoritatif akan membentuk kepribadian anak yang berkarakter yang senantiasa menjujung nilai peradaban bangsa Indonesia. Ada beberapa langkah yang dapat dilakukan oleh orang tua untuk mengembangkan EQ yang sehat yaitu : orang tua menjamin kebutuhan dasar secara layak dan memadai seperti kebutuhan fisiologis (makanan, minuman, sandang, tempat tinggal, dan kebutuhan psikologis yaitu kasih-sayang, perhatian, dankomunikasi, orang tua menyediakan waktu khusus untuk berkomunikasi dan member kasih sayang yang tulus kepada anak-anaknya dengan cara menyediakan waktu untuk berkomunikasi secara intensif membuat anak merasa tenang aman dan dapat memberikan respon positif kepada orang tuanya, orang tua member dukungan social dan mendorong anak-anak untuk melakukan aktivitas-aktivitasnya dengan berani tanpa merasa takut berbuat kesalahan dengan cara menemani anaknya untuk bermain, member motivasi agar dapat melakukan aktivitas-aktivitas yang merangsang perkembangan kognitif, ketram pilan bahasa atau ketrampilan motorik.

\section{BAHAN DAN METODE}

Rancangan penelitian yang digunakan dalam penelitian ini adalah bersifat korelasi. Yaitu menjelaskan hubungan, pola Asuh orang tua dengan perkembangan Emosi anak Prasekolah Berdasarkan waktunya, penelitian ini menggunakan desain cross sectional yakni jenis penelitian yang menekankan pengukuran atau observasi data variabel independen dan dependen hanya satu kali saja pada satu saat. Variabel independen dalam penelitian ini adalah pola asuh orang tua, Sedangkan Variabel dependen dalam penelitian ini adalah Emosi (EQ) anak prasekolah. Populasi dalam penelitian ini yaitu Orang Tua di Perumahan Kahuripan Sidoarjo, sebanyak 80 orangtua, kemudian ditentukan sampel sebanyak 67 orangtua menggunakan rumus Slovin. Setelah mengetahui jumlah sample, peneliti menggunakan simple random sampling dimana setiap responden dalam populasi memilki kesempatan yang sama untuk terpilih maupun tidak terpilih menjadi subyek penelitihan dengan jalan peneliti menulis inisial nama orangtua di Perumahan Kahuripan Sidoarjo dalam kertas kecil, lalu disatukan dalam kotak kecil, kemudian peneliti mengambil secara acak sebanyak 67 orangtua sesuai dengan besar sampel yang dibutuhkan. Sebelum melakukan penelitian, peneliti memberikan inform consent kepada orangtua dengan kriteria sampel bersedia untuk diteliti dan sesuai dengan kriteria sampel untuk penelitian. Instrumen pengambilan data dengan menggunakan kuesioner pada orangtua. Untuk mengetahui pola asuh orang tua dan Perkembangan Emosi (EQ) anak. Sedangkan untuk mengukur kecerdasan emosi (EQ) anak peniliti memberikan pertanyaan melalui wawancara dengan anak.

\section{HASIL}

Hasil pengumpulan data tentang "Hubungan Pola Asuh orang tua dengan perkembangan Emosi anak prasekolah di perumahan Kahuripan Sidoarjo", adalah sebagai berikut. 
1. Karakteristik Responden Berdasarkan Umur Ibu

Tabel 1. Distribusi responden berdasarkan Umur Ibu.

\begin{tabular}{cccc}
\hline No & Umur & f & \% \\
\hline 1 & $20-30 \mathrm{Thn}$ & 29 & $43 \%$ \\
2 & $31-40 \mathrm{Thn}$ & 30 & $45 \%$ \\
3 & $41-50 \mathrm{Thn}$ & 8 & $12 \%$ \\
\hline & Total & 67 & $100 \%$
\end{tabular}

Sumber Data: Kuesioner Penelitian

Berdasarkan tabel 1. dapat diketahui bahwa terbanyak responden dengan Umur 31-40 tahun, yaitu sebanyak 30 responden $(45 \%)$

2. Karakteristik Responden berdasarkan Agama

Tabe1 2. Karakteristik Responden Berdasarkan Agama

\begin{tabular}{|c|c|c|c|}
\hline No & Agama & f & $\%$ \\
\hline 1 & Islam & 57 & $85 \%$ \\
\hline 2 & Kristen & 8 & $12 \%$ \\
\hline 3 & Protestan & 2 & $3 \%$ \\
\hline 4 & Hindu & - & $0 \%$ \\
\hline & Total & 67 & $100 \%$ \\
\hline
\end{tabular}

Berdasarakan Tabe1 2. di atas menunjukkan bahwa terbanyak responden beragama Islam yaitu masing-masing sebanyak 57 responden $(85 \%)$.

3. Karakteristik Responden berdasarkan Pendidikan

Tabel 3. Karakteristik Responden Berdasarkan Pendidikan.

\begin{tabular}{lccc}
\hline No & Pendidikan & f & $\%$ \\
\hline 1 & SD & 2 & $3 \%$ \\
2 & SMP & 12 & $18 \%$ \\
3 & SMA & 33 & $49 \%$ \\
4 & PT & 20 & $30 \%$ \\
\hline & Total & 67 & $100 \%$ \\
\hline
\end{tabular}

Sumber Data: Kuesioner Penelitian

Berdasarkan tabel 3. dapat diketahui bahwa bahwa terbanyak responden dengan Pendidikan SMA, yaitu sebanyak 33 responden (49\%).

4. Karakteristik Responden berdasarkan Pekerjaan
Tabe1 4. Karakteristik Responden Berdasarkan Pekerjaan

\begin{tabular}{llll}
\hline No & \multicolumn{1}{c}{ Pekerjaan } & \multicolumn{1}{c}{ f } & \% \\
\hline 1 & PNS & 6 & $9 \%$ \\
2 & Wiraswasta & 24 & $36 \%$ \\
3 & Tidak bekerja & 10 & $15 \%$ \\
4 & IRT & 27 & $40 \%$ \\
\hline \multicolumn{2}{l}{ Total } & 67 & $100 \%$ \\
\hline \multicolumn{2}{l}{ Sumber Data: Kuesioner } & Penelitian
\end{tabular}

Berdasarkan tabel 4. dapat diketahui bahwa sebagian besar responden sebagai ibu rumah tangga yaitu 27 responden $(40 \%)$

5. Karakteristik Responden berdasarkan Status perkawinan.

Tabe1 5. Karakteristik Responden Berdasarkan Status perkawinan.

\begin{tabular}{cccc}
\hline No & Status Perkawinan & f & \% \\
\hline 1 & Menikah & 66 & $98 \%$ \\
3 & Cerai & 1 & $2 \%$ \\
\hline & Total & 67 & $100 \%$ \\
\hline
\end{tabular}

Sumber Data: Kuesioner Penelitian

Berdasarkan tabel 5. dapat diketahui bahwa sebagian besar responden menikah yaitu sebanyak 66 responden $(98 \%)$.

6. Karakteristik Responden berdasarkan Usia Anak.

Tabe1 6. Karakteristik Berdasarkan Usia Anak

\begin{tabular}{cccc}
\hline NO & Usia Anak & f & \% \\
\hline 1 & $3-4 \mathrm{Th}$ & 37 & $57 \%$ \\
2 & $5-6 \mathrm{Th}$ & 30 & $43 \%$ \\
\hline & Total & 67 & $100 \%$ \\
\hline
\end{tabular}

Sumber Data: Kuesioner Penelitian

Berdasarkan tabel 6. dapat diketahui bahwa sebagian besar usia anak 3-4 tahun, yaitu 37 responden $(57 \%)$.

7. Karakteristik Responden berdasarkan Status Anak

Tabe1 7. Karakteristik Responden Berdasarkan Status anak

\begin{tabular}{llcl}
\hline No & Status anak ke.. & f & \% \\
\hline 1 & Pertama & 30 & $45 \%$ \\
2 & Kedua & 18 & $39 \%$
\end{tabular}




\begin{tabular}{|c|c|c|}
\hline Ketiga & 15 & $10 \%$ \\
\hline Keempat & 4 & $6 \%$ \\
\hline Total & 67 & $100 \%$ \\
\hline
\end{tabular}

Berdasarkan tabel 7. dapat diketahui bahwa sebagian besar status anak pertama yaitu 30 responden (45\%)

8. Hasil pengukuran Karakteristik Pola asuh orang tua denagn emosi (EQ) anak, didapatkan sbb:

Tabel 8. Distribusi data pengukuran Pola asuh orang tua

\begin{tabular}{cccc}
\hline No & Pola Asuh orang tua & $\mathbf{f}$ & $\%$ \\
\hline 1. & Mengabaikan & 17 & $25 \%$ \\
2. & Menyetujui & 1 & $2 \%$ \\
3. & Laissez-Faire & 25 & $37 \%$ \\
4 & Pelatihan Emosi & 24 & $36 \%$ \\
\hline & Total & 67 & $100 \%$ \\
\hline
\end{tabular}

Sumber Data: Kuesioner Penelitian

Berdasarkan tabel 8. didapatkan data bahwa sebagian besar Pola Asuh yang digunakan Laize-Faire sebanyak 25 orang $(37 \%)$.

9. Hasil pengukuran karakteristik Kecerdasan Emosi (EQ) anak

Tabel 9. Distribusi data pengukuran Karakteristik Emosi anak

\begin{tabular}{cccc}
\hline No & Kecerdasan Emosi & f & \% \\
\hline 1. & Baik & 21 & $31 \%$ \\
2. & Tidak baik & 46 & $69 \%$ \\
\hline & Total & 67 & $100 \%$ \\
\hline
\end{tabular}

SumberData : Kuesioner Penelitian

Berdasarkan tabel 9. didapatkan data bahwa sebagian besar kecerdasan emosi anak tidak baik yaitu 46 anak (69\%).

10.Distribusi silang Pola Asuh orang tua dan Emosi (EQ) anak.

Tabel 10. Tabulasi silang distribusi data frekuensi sebelum dan sesudah dilakukan pemberian Jus buah naga. (Hylocereus Polyrhizus).

\begin{tabular}{cccccc}
\hline No & Kategori & \multicolumn{3}{c}{ Kecerdasan Emosi $($ EQ) } \\
\cline { 3 - 5 } & & baik & $(\%)$ & $\begin{array}{c}\text { Tdk } \\
\text { baik }\end{array}$ & $(\%)$ \\
\hline 1. & Mengabaikan & 2 & $17 \%$ & 15 \\
\hline
\end{tabular}

\begin{tabular}{cccccc}
\hline 2. & Menyetujui & 0 & $0 \%$ & 1 & \\
\hline 3. & Laissez-Faire & 5 & $20 \%$ & 20 & \\
\hline 4. & Pelatihan Emosi & 14 & $57 \%$ & 10 & \\
\hline & Total & 21 & $94 \%$ & 46 & $\begin{array}{c}100 \\
\%\end{array}$
\end{tabular}

Hasil uji spearman $\mathbf{p}=\mathbf{0 , 0 0 6}(\mathrm{P}<\mathbf{0 , 0 5})$

Sumber Data: Kuesioner Penelitian

Berdasarkan tabel 10. dapat diketahui bahwa pola asuh yang terbanyak digunakan adalah pola asuh LaissezFaire sebanyak 25 responden. 5 diantaranya memiliki perkembangan emosi yang baik selebihnya 20 responden yang memiliki perkembangan emosi yang tidak baik. Uji staistik dilakukan untuk mengetahui hipotesis yang diajukan diterima atau ditolak. Untuk menguji apakah terdapat perbedaan antara hubungan pola asuh orang tua terhadap perkembangan emosi (EQ) pada anak prasekolah, peneliti menggunakan uji statistik spearman's melalui komputerisasi dengan derajat kemaknaan $\mathrm{p}<0,05$. Hasil yang diperoleh yaitu signifikan sebesar 0,006. Karena $\mathrm{P}<0,05$ maka H-0 ditolak, dan $\mathrm{H} 1$ diterima, jadi terdapat perbedaan antara hubungan pola asuh terhadap perkembangan emosi pada anak prasekolah.

\section{PEMBAHASAN}

Pada pembahasan akan diuraikan hasil penelitian hubungan pola asuh orang tua terhadap perkembangan emosi (EQ) pada anak prasekolah di perumahan Kahuripan Sidoarjo. Dari hasil penelitian di perumahan Kahuripan di dapatkan hasil sebagai berikut:

\section{Pola asuh orang tua pada anak prasekolah}

Berdasarkan penelitian pada responden gaya pola asuh orang tua yang terbanyak memakai pola asuh Laissez-Faire sebanyak 25 responden (37\%). (Edwad, 2006) faktor-faktor yang mempengaruhi pola asuh anak anatara lain: pendidikan orang tua, lingkungan, budaya, dan usia.

Berdasarkan tabel Karakteristik responden berdasarkan umur didapatkan hasil responden terbanyak berusia usia 
31-40 tahun yaitu sebanyak 30 orang (45\%). Menurut Notoadmojo (2003) semakin cukup umur seseorang, maka tingkat kematangan dan kekuatan seseorang akan lebih matang dalam berfikir dan semakin tambahnya usia seseorang semakin dapat menggunakan koping yang dihadapi. berdasarkan fakta yang terbesar responden berusia 31-40 tahun berarti sebagian besar responden memiliki kematangan emosi yang baik karena kematangan emosi dipengaruhi oleh usia seseorang. Usia tidak selalu menentukan cara berfikir dan prilaku seseorang, terkadang terdapat usia yang matang namun prilakunya tidak sesuai dengan usianya. Terlebih lagi dalam hal ini, walaupun orang tua berusia matang belum tentu memberikan pola asuh yang baik. Hal ini dapat juga dipengaruhi oleh pengalaman sesorang dalam mengasuh sebelumnya dan kurangnya informasi tentang pola asuh anak yang tidak didapatkan di pendidikan melainkan mencari informasi sendiri dari sumbersumber yang ada. Usia juga tidak menjadikan patokan orang tua dalam mengasuh anak, karena usia yang matang belum tentu mempunyai pengalaman yang baik untuk mengasuh anak.

Berdasarkan table Responden berdasarkan pendidikan terakhir orang tua yang terbanyak yaitu, SMA sebanyak 32 orang (49\%). Supartini (2004) pendidikan dan pengalaman orang tua dalam perawatan anak akan memepengaruhi persiapan mereka menjalankan pengasuhan. Ada beberapa cara yang dapat dilakukan untuk menjadi lebih siap dalam menjalankan peran pengasuhan antara lain: telibat aktif dalam setiap pendidikan anak, selalu berupaya menyediakan waktu untuk anak-anak dan menilai perkembangan fungsi keluarga dan kepercayaan anak. Hasil riset dari Sir Godfrey Thomson menunjukan bahwa pendidikan diartikan sebagai pengaruh lingkungan atas individu untuk menghasilkan perubahan yang tetap atau permanen di dalam kebiasaan tingkah laku, pikiran, dan perkembangan.
Berdasarkan tingkat pendidikan responden sebagian besar berpendidikan SMA yang berarti responden memiliki cukup pengetahuan dalam mengasuh anak. akan tetapi pada kasus nyata banyak responden dengan pendidikan SMA yang masih belum mengerti cara mengasuh anak dengan baik, dikarenakan pengetahuan dan informasi tetang pola asuh anak yang mereka terima belum cukup dari pendidikan di sekolah.

\section{Kecerdasan Emosi (EQ) pada anak prasekolah.}

Berdasarkan hasil penelitian kecerdasan emosi pada anak yang terbanyak tidak baik sebanyak 46 anak (69\%). (Andreas Hartanto,2012) menyatakan bahwa ada 3 faktor yang mempengaruhi kecerdasan emosi yaitu, faktor psikologis, faktor pelatihan emosi, dan faktor penddikan. Maka emosi (EQ) anak yang tidak baik banyak dipengaruhi oleh faktor psikologis anak yaitu anak tidak mampu mengolah, mengontrol, dan mengendalikan emosi secara efektif dan faktor pendidikan yang belum tercapai.

Berdasarkan table karakteristik Berdasarkan usia anak, yang terbanyak berusia 3 - 4 anak yaitu 37 orang (57\%). Piaget menjelaskan karateristik utama anak prasekolah adalah egosentris, Egosentris pada anak prasekolah tidak berarti mereka mementingkan diri sendiri, tetapi karena mereka tidak melihat sesuatu dari sudut pandang orang lain. Usia anak sangat mempengaruhi emosi (EQ) anak tersebut, pada usia prasekolah anak cenderung egoisentris Maka peran orang tua dalam mengasuh anak harus baik dalam memilih pola asuh mana yang baik untuk diterapkan sejak dini karena, penerapan pola asuh yang baik dapat merubah karakteristik anak dari egosentris menjadi tidak egoisentris sampai anak dewasa.

Menurut Siregar (2007) yang
mengatakan bahwa pengetahuan
seseorang bukan hanya dipengaruhi oleh


tingkat pendidikan, karena pengetahuan tidak hanya didapat dari bangku sekolah, namun pengetahuan lebih banyak diperoleh dari pengalaman hidup dan informasi yang diperoleh. Orang tua yang memiliki pengalaman anak sebelumnya akan lebih matang mengasuh anaknya, hal ini dikarenakan orang tua telah mampu menilai pengasuhan yang cocok untuk diterapkan kepada anaknya. Akan tetapi ada juga orang tua yang berpengalaman mengasuh anak namun tidak dapat memberikan gaya pola asuh terhadap anaknya karena minimnya pengetahuan dan informasi orang yang dapat juga mempengaruhi.

3. Hubungan pola asuh orang tua dengan perkembangan Emosi (EQ) anak prasekolah.

Berdasarkan hasil penelitian dan data dari tabel 4.10 pola asuh terbanyak menggunakan gaya lessez- faire sebanyak 25 reponden diantaranya 5 perkembangan emosinya baik, selebihnya 20 responden perkembangan emosinya tidak baik. Menurut hasil uji Spearmen bahwa nilai $\mathrm{P}=0,006$ karena $\mathrm{P}$ kurang dari $0,05 \mathrm{H}-0$ ditolak sehingga terdapat hubungan antara pola asuh orang tua terhadap perkembangan emosi anak prasekolah. Menurut Goleman (2007) kecerdasan emosi erat kaitanya dengan keadaan otak emosional. Faktor yang dapat mempengaruhi kecerdasan emosi yaitu faktor psikologis, pelatihan emosi, dan faktor pendidikan. Jadi pola asuh oarang tua yang membiarkan dapat berdampak negatif pada perkembanagan kecerdasan emosi (EQ) pada anak. Sehingga orang tua harus dapat memberikan pola asuh yang tepat terhadap anak mereka, agar perkembangan emosi anak dapat optimal. Pola asuh orang tua sangat menentukan perkembangan emosi anak, oleh karena itu orang tua harus dapat menerapkan pola asuh yang sesuai terhadap anak karena hal tersebut dapat berdapak pada perkembangan emosi anak yang bahkan dibawa hingga anak dewasa.

\section{SIMPULAN}

Berdasarkan hasil penelitian yang telah dilakukan oleh peneliti maka dapat ditarik kesimplan yaitu:

1. Mayoritas orang tua $(80 \%)$ di perumahan Kahuripan menerapkan pola asuh Laissez-faire.

2. Sebagian besar anak (69\%) di perumahan Kahuripan mengalami perkembangan emosi yang tidak baik.

3. Terdapat hubungan pola asuh orang tua dengan perkembangan emosi (EQ) anak prasekolah di Perumahan Kahuripan Blok CA 17 dan 35 Sidoarjo dengan signifikasi $\mathrm{p}<0,006$.

\section{SARAN}

Saran yang dapat diberikan oleh peneliti berdasarkan kesimpulan diatas adalah orangtua diharapkan untuk tidak menggunakan pola asuh Lissez-Faire

\section{DAFTAR PUSTAKA}
Dariyo, Agus (2007). Psikologi Perkembangan Anak Tiga Tahun Pertama. Bandung: PT Refika Aditama

Hidayat, Aziz Alimul. (2007). Riset Keperawatan dan Teknik Penulisan Ilmiah. Jakarta: Salemba Medika

Hurlock, Elizabeth B. (1995). Perkembangan Anak Edisi ke Enam. Jakarta: Erlangga

Ilahi, Takdir Mohammad. (2003). Quantum Parenting Kiat Sukses Efektif Mengasuh Anak Secara Efektif Dan Cerdas. Jogjakarta; AR-RUZZ MEDIA

Nursalam. (2008). Konsep dan Penerapan Metodologi Penelitian IlmuKeperawatan Pedoman Skripsi, Tesis, dan Instrumen Penelitian Keperawatan. Edisi 2. Jakarta: Salemba Medika 
Setiadi. (2007). Konsep Dan Penulisan Riset Keperawatan. Yogyakarta: Graha Ilmu

Soejtiningsih. (2010). Tumbuh Kembang Anak. Jakarta: EGC

Wiyani, Novan Ardy, M.Pd.i. Bina Karakter Anak Usia Dini Panduan Orang Tua dan Guru dalam Membentuk Kemandirian Anak Usia Dini. Jogjakarta: AR-RUZZ MEDIA

Yamin, Martinis, M.Pd dan Dr. Jamila Sabri Sanam, M.Pd. Panduan PAUD (Pendidikan Anak Usia Dini). Jakarta: Refrensi (Gaung Persada Press Group)

Goleman, D. (1997). Emotional Intelligence.Jakarta: PT Gramedia Pustaka Utama

Hurlock, E.B. (1997). Psikologi Perkembangan Suatu Pendekatan Sepanjang Rentang Kehidupan. Edisi Kelima.Jakarta: Erlangga

Potter \& Perry. (2005). Buku Ajar Fundamental Keperawatan: Konsep, Proses, dan Praktik. Jakarta: EGC

Malahayati. (2009). Siap Menjadi Genius Sejak Dini IQ, EQ, SQ untuk anak usia 3-7 Tahun. Jakarta: Kendi Mas Media

Habibi, M. (2007). Jurnal Program Bimbingan Bagi Orang Tua Dalam Penerapan Pola Asuh Untuk Meningkatkan Kematangan Sosial Anak (Studi Kasus Anakm dan Orang Tua Di TK Islam Terpadu Anak Sholeh Mataram). Bandung: Universitas Pendidikan Indonesia (tidak dipublikasikan) 